\title{
GFPMX: A Cobweb Model of the Global Forest Sector, with an Application to the Impact of the COVID-19 Pandemic
}

\author{
Joseph Buongiorno
}

Department of Forest and Wildlife Ecology, University of Wisconsin, Madison, WI 53705, USA; jbuongio@wisc.edu

\begin{abstract}
The GFPMX projects forest area and stock, consumption, production, imports, exports, and prices of industrial roundwood, fuelwood, sawnwood, wood-based panels, wood pulp, and paper and paperboard in 180 countries, and currently from 2018 to 2070 . The core principle of the model is the cobweb theorem, according to which markets are not necessarily in equilibrium, but take some time to adjust to shocks—such as demand shifts-leading to oscillatory dynamics of prices and quantities. This paper presents the model's structure and the estimation of its parameters from international statistics on production, trade, forest area, and forest stock. This is followed by an application of the GFPMX to the impact on the global forest sector of the economic recession caused by the COVID-19 pandemic.
\end{abstract}

Keywords: forestry; forest industries; forest products trade; modeling; cobweb; COVID-19

Citation: Buongiorno, J. GFPMX: A Cobweb Model of the Global Forest Sector, with an Application to the Impact of the COVID-19 Pandemic. Sustainability 2021, 13, 5507.

https://doi.org/10.3390/su13105507

Academic Editors: Ragnar Jonsson and Paul Rougieux

Received: 25 April 2021

Accepted: 11 May 2021

Published: 14 May 2021

Publisher's Note: MDPI stays neutral with regard to jurisdictional claims in published maps and institutional affiliations.

Copyright: (C) 2021 by the author. Licensee MDPI, Basel, Switzerland. This article is an open access article distributed under the terms and conditions of the Creative Commons Attribution (CC BY) license (https:// creativecommons.org/licenses/by/ $4.0 /)$.

\section{Introduction}

This paper presents a model of the global forest sector, GFPMX, designed to project the forest area and stock for multiple countries and years, along with the annual consumption, production, import, export, and price of major wood products.

Unlike other forest sector models [1-4] that use partial equilibrium theory $[5,6]$, the GFPMX relies on the cobweb theorem [7-9]. In this view, instead of following a succession of perfect equilibria, a dynamic economy tends to only converge gradually towards an equilibrium, typically in oscillating patterns, without necessarily reaching it.

The proposed model also assumes that demand creates its own supply [10], in contrast with Say's law [11]. Thus, in the GFPMX, domestic and import demand are the driving forces in the evolution of the global forest sector. Export supply is pulled by the global demand for imports, and domestic production meets net demand (consumption minus imports plus exports). The world price then depends on production, the price of inputs, and forest stock, while the local price is a function of the world price. Forest area changes along an environmental Kuznets curve [12], while forest stock varies according to a growth-drain equation [13].

The first part of this paper presents the mathematical formulation of the GFPMX. This is followed by a description of the methods used to estimate the model parameters, and of the Excel@ software employed to implement the model. As an example of potential applications, the GFPMX was used to project the effects on the global forest sector of the economic recession induced by the COVID-19 pandemic-a catastrophe "unprecedented in its global reach and impact, posing formidable challenges to policymakers and to the empirical analysis of its direct and indirect effects within the interconnected global economy" [14]. The GFPMX was applied to simulate two scenarios, with and without the COVID-19 pandemic, based on the economic growth projections of the International Monetary Fund. Due to the pandemic, the global production of forest industries was nearly $\$ 35$ billion less $(-2.7 \%)$ in 2020 and still $\$ 32$ billion less in 2030, while global trade was $\$ 11$ billion less (-4.5\%) in 2020 and nearly \$10 billion less in 2030. 


\section{Model Formulation}

The GFPMX model was designed to predict for each county $(i)$ and year $(t)$ the consumption, production, import, export, and price of fuelwood $(f)$, industrial roundwood $(r)$, sawnwood $(s)$, wood-based panels $(l)$, wood pulp $(u)$, and paper and paperboard (a). The model also projects for each year and country the forest area and the volume of growing stock.

\subsection{Domestic Demand of End Products}

The consumption of each of these end products is a function of the local price lagged one period (in accordance with the cobweb theorem), and of the current gross domestic product, with country- and product-specific parameters:

$$
C_{i k t}=\alpha_{i k} P_{i k, t-1}^{\beta_{i k}} Y_{i t}^{\gamma_{i k}} \quad \forall k=f, s, l, a
$$

$C_{i k t}=$ consumption of product $k$ in country $i$ and year $t$;

$P_{i k, t-1}=$ lagged price of product $k$ in country $i$;

$Y_{i t}=$ gross domestic product in country $i$ and year $t ;$

$\alpha_{i k}, \beta_{i k}, \gamma_{i k}=$ country- and product-specific parameters;

$f=$ fuelwood; $s$ = sawnwood; $l=$ wood-based panels; $a=$ paper and paperboard

\subsection{Domestic Demand for Wood Pulp}

Wood pulp is used to make paper and paperboard. Depending on its price, wood pulp can be substituted by other fibers. Thus, domestic consumption is a function of the local price of wood pulp lagged one period, and of the production of paper and paperboard, with country-specific parameters:

$$
C_{i u t}=\alpha_{i u} P_{i u, t-1}^{\beta_{i u}} Q_{i a t}^{\gamma_{i u}}
$$

$C_{i u t}=$ consumption of wood pulp in country $i$ and year $t$;

$P_{i u, t-1}=$ lagged price of wood pulp in country $i$;

$Q_{\text {iat }}=$ production of paper and paperboard in country $i$ and year $t$;

$\alpha_{i u}, \beta_{i u}, \gamma_{i u}=$ country-specific parameters.

\subsection{Domestic Demand for Industrial Roundwood}

The domestic consumption of industrial roundwood is a function of its price lagged one period, and of the production of products made with industrial roundwood, with country-specific parameters:

$$
C_{i r t}=\alpha_{i r} P_{i r, t-1}^{\beta_{i r}}\left(Q_{i s t}+Q_{i l t}+Q_{i u t}\right)^{\gamma_{i r}}
$$

$C_{i r t}=$ consumption of industrial roundwood in country $i$ and year $t$;

$P_{i r, t-1}=$ lagged price of industrial roundwood in country $i$;

$Q_{i s t}, Q_{i l t}, Q_{i u t}=$ production of sawnwood, wood-based panels, and wood pulp, respectively; $\alpha_{i r}, \beta_{i r}, \gamma_{i r}=$ country-specific parameters.

The import demand equations have the same form as the domestic demand Equations (1)-(3), but with different product- and country-specific parameters. Furthermore, the price is augmented by potential import tariffs.

2.4. Import Demand for Fuelwood, Sawnwood, Panels, Paper and Paperboard

$$
I_{i k t}=\alpha_{i k}\left[\left(1+\tau_{i k, t-1}\right) P_{i k, t-1}\right]^{\beta_{i k}} Y_{i t}^{\gamma_{i k}} \forall k=f, s, l, a
$$

$I_{i k t}=$ import of product $k$ in country $i$ and year $t$;

$P_{i k, t-1}=$ lagged price of product $k$ in country $i$;

$Y_{i t}=$ gross domestic product in country $i$ and year $t$; 
$\tau_{i k, t-1}=$ ad valorem tariff on imports of product $k$ in country $i$, at $t-1$;

$\alpha_{i k}, \beta_{i k}, \gamma_{i k}=$ country- and product-specific parameters.

2.5. Import Demand for Wood Pulp

$$
I_{i u t}=\alpha_{i u}\left[\left(1+\tau_{i u, t-1}\right) P_{i u, t-1}\right]^{\beta_{i u}} Q_{i a t}^{\gamma_{i u}}
$$

$I_{i u t}=$ import of wood pulp in country $i$ and year $t$;

$P_{i u, t-1}=$ lagged price of wood pulp in country $i$;

$Q_{i a t}=$ production of paper and paperboard in country $i$ and year $t$;

$\tau_{i u, t-1}=$ ad-valorem tariff on imports of wood pulp in country $i$, at $t-1$;

$\alpha_{i u}, \beta_{i u}, \gamma_{i u}=$ country-specific parameters.

\subsection{Import Demand for Industrial Roundwood}

$$
I_{i r t}=\alpha_{i r}\left[\left(1+\tau_{i r, t-1}\right) P_{i r, t-1}\right]^{\beta_{i r}}\left(Q_{i s t}+Q_{i l t}+Q_{i u t}\right)^{\gamma_{i r}}
$$

$I_{i r t}=$ import of industrial roundwood in country $i$ and year $t$;

$P_{i r, t-1}=$ lagged price of industrial roundwood in country $i$;

$Q_{i s t}, Q_{i l t}, Q_{i u t}=$ production of sawnwood, wood-based panels, and wood pulp, respectively; $\tau_{i r, t-1}=$ ad valorem tariff on imports of industrial roundwood in country $i$, at $t-1$;

$\alpha_{i r}, \beta_{i r}, \gamma_{i r}=$ country-specific parameters.

\subsection{Export Supply}

Exports of a product from a country depend on the volume of global imports according to a "marginal propensity to export" equation, analogous to the "marginal propensity to consume" of macroeconomics-a linear function of world imports. This functional form and the country-specific parameters estimated by ordinary least squares ensure that the sum of all countries' predicted exports equals total world imports (a difference may remain insofar as the data on world imports differ from world exports):

$$
X_{i k t}=\delta_{i k}+\theta_{i k} I_{\text {wkt }} \forall k=f, s, l, a, u, r
$$

$X_{i k t}=$ export of product $k$ from country $i$ in year $t$;

$I_{w k t}=\sum_{i=1}^{n} I_{i k t}=$ world imports of product $k$ in year $t, n=$ number of countries;

$\delta_{i k}, \theta_{i k}=$ country- and product-specific parameters;

$\theta_{i k}=$ marginal propensity to export product $k$ from country $i$.

\subsection{Domestic Production}

For each product and country, the domestic production is assumed to meet net demand, determined by domestic consumption (Equations (1)-(3)), imports (Equations (4)-(6)), and exports (Equation (7)), according to:

$$
Q_{i k t}=C_{i k t}+X_{i k t}-I_{i k t} \forall k=f, s, l, a, u, r
$$

$Q_{i k t}=$ production of product $k$ in country $i$ and year $t$.

\subsection{World Price of Industrial Roundwood}

The world price of industrial roundwood is a function of the quantity produced (as in an inverse supply function), of the level of growing stock, and of a time trend:

$$
P_{w r t}=\vartheta_{r} Q_{w r t}^{\mu_{r}} S_{w t}^{\pi_{r}} e^{\rho_{r} t}
$$

$P_{\text {wrt }}=$ world price of industrial roundwood in year $t$;

$Q_{w r t}=\sum_{i=1}^{n} Q_{i r t}=$ world production of industrial roundwood in year $t$, in $n$ countries;

$S_{w k t}=\sum_{i=1}^{n} S_{i k t}=$ world forest growing stock in year $t$, in $n$ countries; 
$\vartheta_{r}, \mu_{r}, \pi_{r}, \rho_{r}=$ parameters.

2.10. World Price of Fuelwood, Sawnwood, Wood Pulp, and Wood-Based Panels

For these products the world price is a function of the world price of industrial roundwood, the main input for sawnwood, wood pulp, and wood-based panels, and the main competitor for fuelwood:

$$
P_{w k t}=\vartheta_{k} P_{w r, t}^{\pi_{k}} \forall k=f, s, u, l
$$

$P_{w k t}=$ world price of product $k$ in year $t$;

$P_{\text {wrt }}=$ world price of industrial roundwood in year $t$;

$\vartheta_{k}, \pi_{k}=$ parameters.

\subsection{World Price of Paper and Paperboard}

The world price of paper and paperboard depends on the world price of wood pulp (the main input in making paper and paperboard):

$$
P_{w a t}=\vartheta_{a} P_{w u t}^{\pi_{a}}
$$

$P_{\text {wat }}=$ world price of paper and paperboard in year $t$;

$P_{w u t}=$ world price of wood pulp in year $t$;

$\vartheta_{a}, \pi_{a}=$ parameters

\subsection{Local Price}

The local price, one of the determinants of domestic and import demand, depends on the world price:

$$
P_{i k, t}=\sigma_{i k} P_{w k, t}^{\tau_{i k}} \forall i, k, t
$$

$P_{i k, t}=$ price of product $k$ in country $i$ and year $t$;

$P_{w k, t}=$ world price of product $k$ in country $i$ and year $t$;

$\sigma_{i k}, \tau_{i k}=$ parameters.

\subsection{Forest Area}

Forest area changes at an annual rate that depends on economic development:

$$
A_{i t}=A_{i, t-1}\left(1+g_{i, t}\right)
$$

$A_{i t}=$ forest area in country $i$ and year $t$;

$g_{i t}=$ annual growth rate of forest area, in country $i$ and year $t$. This growth rate changes over time according to an "environmental Kuznets curve" equation linking the rate of growth to the level of GDP per capita:

$$
g_{i t}=\left(\varphi_{i}+\omega y_{i t}\right) e^{\vartheta y_{i t}}
$$

$y_{i t}=$ GDP per capita in country $i$ and year $t$;

$\varphi_{i}=$ country-specific constant;

$\omega, \vartheta=$ parameters. With $\omega>0$ and $\vartheta<0$, the growth rate of forest area is negative at low levels of GDP per capita-implying deforestation-becomes positive at higher levels-implying afforestation-and converges to zero with positive values at very high levels of GDP per capita, implying a stabilization of forest area.

\subsection{Forest Stock}

The forest stock in each country changes over time according to the following growthdrain equation:

$$
S_{i t}=S_{i, t-1}\left(1+\sigma_{i}\right)-\alpha_{i}\left(Q_{i f, t-1}+Q_{i r, t-1}\right)
$$

$S_{i t}=$ forest stock in country $i$ and year $t$; 
$Q_{i f, t-1}=$ lagged fuelwood production in country $i$;

$Q_{i r, t-1}=$ lagged industrial roundwood production in country $i$;

$\sigma_{i}=$ growth rate of forest stock, without harvest, in country $i$;

$\alpha_{i}>0=$ influence of harvest on forest stock in country $i$.

\section{Data and Parameters Estimation}

\subsection{Data}

The data used to estimate the parameters of the GFPMX equations were annual statistics from 180 countries, from 1992 to 2018. The data on production, imports, and exports in quantity and value came from FAOSTAT [15]. The data on population and real GDP in constant United States dollars (USD), and the data on the United States GDP deflator, came from the World Bank Development Indicators database [16]. The world price for each commodity group was the unit value of world exports, and the local price was the unit value of imports for net exporting countries, or the unit value of exports for net exporting countries. For countries with no import or export the local price was the world price. All prices were expressed in constant United States dollars of 2017. The data on forest area and forest stock came from the Forest Resources Assessment of the Food and Agriculture Organization of the United Nations [17].

\subsection{Domestic Demand and Import Demand Parameters}

The country-specific parameters of Equations (1)-(6) were obtained by minimizing the sum of the squares of the differences between the observed and predicted logarithm of consumption, or imports, given the local price and demand shifters, for all products and countries, conditional on a priori upper and lower bounds on the elasticities. For example, the country- and product-specific parameters of the domestic demand Equation (1) were obtained by solving the following quadratic program [18]:

Find the parameters $\beta_{i k}^{+}, \beta_{i k^{\prime}}^{-} \gamma_{i k}^{+}, \gamma_{i k}^{-}, \alpha_{i k}^{+}, \alpha_{i k}^{-} \geq 0 \forall i, k$;

such that:

$$
\min S S Q R=\sum_{i k t}\left(\ln C_{i k t}-\ln \hat{C}_{i k t}\right)^{2}
$$

subject to:

$$
\begin{gathered}
\ln \hat{C}_{i k t}=\beta_{i k} \ln P_{i k, t-1}+\gamma_{i k} \ln Y_{i k t}+\alpha_{i k} \forall i, k \\
\beta_{i k}^{L} \leq \beta_{i k}=\beta_{i k}^{+}-\beta_{i k}^{-} \leq \beta_{i k}^{U} \forall i, k \\
\gamma_{i k}^{L} \leq \gamma_{i k}=\gamma_{i k}^{+}-\gamma_{i k}^{-} \leq \gamma_{i k}^{U} \forall i, k \\
\alpha_{i k}=\alpha_{i k}^{+}-\alpha_{i k}^{-} \forall i, k
\end{gathered}
$$

where the superscripts $L$ and $U$ in Equations (18) and (19) refer to a priori lower and upper bounds on the parameters.

The results summary for domestic demand (Table 1) shows that the mean price elasticity of demand, over all countries, varied from -0.38 for paper and paperboard to -0.16 for industrial roundwood. The mean GDP elasticity varied from 0.17 for fuelwood to 0.67 for wood-based panels. The mean elasticity of wood pulp demand with respect to paper and paperboard production was 0.75 , while the mean elasticity of industrial roundwood demand with respect to the sum of sawnwood, wood-based panels, and pulp production was 0.56 . All mean values of the elasticities were statistically significant at least at the 0.01 level.

For import demand (Table 2), the mean price elasticity over all countries varied from -0.47 for paper and paperboard to -0.12 for fuelwood. The mean GDP elasticity varied from 0.15 for fuelwood to 0.75 for wood-based panels. The mean elasticity of wood pulp import demand with respect to paper and paperboard production was 0.62 , and the mean elasticity of industrial roundwood import demand with respect to the sum of sawnwood, wood-based panels, and pulp production was 0.28 . All mean values of the elasticities were statistically significant at least at the 0.01 level. 
Table 1. Summary statistics of country-specific elasticities of domestic demand with respect to price and shifters, byproduct.

\begin{tabular}{|c|c|c|c|c|c|c|c|}
\hline \multirow{2}{*}{ Product } & \multicolumn{3}{|c|}{ Elasticity } & \multirow{2}{*}{ Product } & \multicolumn{3}{|c|}{ Elasticity } \\
\hline & & Price & Shifter & & & Price & Shifter \\
\hline \multirow[t]{4}{*}{ Sawnwood $^{1}$} & $\max$ & -0.05 & 1.00 & Wood pulp ${ }^{2}$ & $\max$ & -0.05 & 1.00 \\
\hline & $\min$ & -1.00 & 0.00 & & $\min$ & -1.00 & 0.00 \\
\hline & mean & -0.31 & 0.45 & & mean & -0.28 & 0.75 \\
\hline & SE & 0.02 & 0.03 & & SE & 0.03 & 0.03 \\
\hline \multirow[t]{4}{*}{ Wood-based panels ${ }^{1}$} & $\max$ & -0.05 & 1.00 & Industrial roundwood ${ }^{3}$ & $\max$ & -0.05 & 1.00 \\
\hline & $\min$ & -1.00 & 0.00 & & $\min$ & -1.00 & 0.00 \\
\hline & mean & -0.32 & 0.67 & & mean & -0.16 & 0.56 \\
\hline & SE & 0.02 & 0.03 & & SE & 0.02 & 0.03 \\
\hline \multirow[t]{4}{*}{ Paper and paperboard ${ }^{1}$} & $\max$ & -0.05 & 1.00 & Fuelwood $^{1}$ & $\max$ & -0.05 & 1.00 \\
\hline & $\min$ & -1.00 & 0.00 & & $\min$ & -1.00 & -1.00 \\
\hline & mean & -0.38 & 0.55 & & mean & -0.17 & 0.17 \\
\hline & SE & 0.03 & 0.03 & & SE & 0.02 & 0.04 \\
\hline
\end{tabular}

${ }^{1}$ Shifter $=$ gross domestic product; ${ }^{2}$ Shifter $=$ paper and paperboard production; ${ }^{3}$ Shifter $=$ sawnwood, wood-based panel, and pulp production.

Table 2. Summary statistics of country-specific elasticity of import demand with respect to product price and shifters, by product.

\begin{tabular}{|c|c|c|c|c|c|c|c|}
\hline \multirow{2}{*}{ Product } & \multicolumn{3}{|c|}{ Elasticity } & \multirow{2}{*}{ Product } & \multicolumn{3}{|c|}{ Elasticity } \\
\hline & & Price & Shifter & & & Price & Shifter \\
\hline \multirow[t]{4}{*}{ Sawnwood $^{1}$} & $\max$ & -0.05 & 1.00 & Wood pulp ${ }^{2}$ & $\max$ & -0.05 & 1.00 \\
\hline & $\min$ & -1.00 & 0.00 & & $\min$ & -1.00 & 0.00 \\
\hline & mean & -0.39 & 0.50 & & mean & -0.17 & 0.62 \\
\hline & SE & 0.03 & 0.03 & & SE & 0.02 & 0.03 \\
\hline \multirow[t]{4}{*}{ Wood-based panels ${ }^{1}$} & $\max$ & -0.05 & 1.00 & Industrial roundwood ${ }^{3}$ & $\max$ & -0.05 & 1.00 \\
\hline & $\min$ & -1.00 & 0.00 & & $\min$ & -1.00 & 0.00 \\
\hline & mean & -0.37 & 0.75 & & mean & -0.25 & 0.28 \\
\hline & SE & 0.03 & 0.03 & & SE & 0.02 & 0.03 \\
\hline \multirow[t]{4}{*}{ Paper and paperboard ${ }^{1}$} & $\max$ & -0.05 & 1.00 & Fuelwood $^{1}$ & $\max$ & -0.05 & 1.00 \\
\hline & $\min$ & -1.00 & 0.00 & & $\min$ & -1.00 & -1.00 \\
\hline & mean & -0.47 & 0.63 & & mean & -0.12 & 0.15 \\
\hline & SE & 0.03 & 0.03 & & SE & 0.02 & 0.04 \\
\hline
\end{tabular}

${ }^{1}$ Shifter = gross domestic product; ${ }^{2}$ Shifter $=$ paper and paperboard production; ${ }^{3}$ Shifter $=$ sawnwood, wood-based panel, and pulp production.

\subsection{Export Supply Parameters}

The country- and product-specific marginal propensities to export were obtained by minimizing the sum of squares of the difference between predicted and observed exports, given observed world imports, with the following quadratic program:

Find the parameters $\delta_{i k}^{+}, \delta_{i k}^{-}, \theta_{i k}^{+}, \theta_{i k}^{-} \geq 0 \forall i, k$;

such that:

$$
\min S S Q R_{i k t}=\sum_{i k t}\left(X_{i k t}-\hat{X}_{i k t}\right)^{2}
$$

subject to:

$$
\begin{gathered}
\hat{X}_{i k t}=\delta_{i k}+\theta_{i k} I_{w k t} \quad \forall i, k \\
\delta_{i k}=\delta_{i k}^{+}-\delta_{i k}^{-} \quad \forall i, k \\
\theta_{i k}=\theta_{i k}^{+}-\theta_{i k}^{-} \quad \forall i, k
\end{gathered}
$$

Because reported world exports differ from world imports, the estimation was performed by replacing $I_{w k t}$ with $X_{w k t}=\sum_{i=1}^{n} X_{i k t}$. The results summary (Table 3) shows that the mean of the marginal propensity to export $\left(\theta_{i k}\right)$, across all countries was the same for all products- 0.006 - while in individual countries it ranged from -0.117 for wood-based 
panels to 0.386 for wood pulp. All mean values of the marginal propensities to export were statistically significant at least at the 0.01 level.

Table 3. Summary statistics of country-specific marginal propensity to export $\left(\theta_{i k}\right)$, by product.

\begin{tabular}{|c|c|c|c|c|c|}
\hline \multirow{2}{*}{$\begin{array}{c}\text { Product } \\
\text { Sawnwood }\end{array}$} & \multicolumn{2}{|c|}{$\theta_{i k}$} & \multirow{2}{*}{$\begin{array}{c}\text { Product } \\
\text { Wood pulp }\end{array}$} & \multicolumn{2}{|c|}{$\theta_{i k}$} \\
\hline & $\max$ & 0.334 & & $\max$ & 0.386 \\
\hline & $\min$ & -0.033 & & $\min$ & -0.044 \\
\hline & mean & 0.006 & & mean & 0.006 \\
\hline & SE & 0.002 & & SE & 0.002 \\
\hline \multirow[t]{4}{*}{ Wood-based panels } & $\max$ & 0.258 & Industrial roundwood & $\max$ & 0.156 \\
\hline & $\min$ & -0.117 & & $\min$ & -0.064 \\
\hline & mean & 0.006 & & mean & 0.006 \\
\hline & SE & 0.002 & & SE & 0.002 \\
\hline \multirow[t]{4}{*}{ Paper and paperboard } & $\max$ & 0.181 & Fuelwood & $\max$ & 0.229 \\
\hline & $\min$ & -0.077 & & $\min$ & -0.034 \\
\hline & mean & 0.006 & & mean & 0.006 \\
\hline & SE & 0.002 & & SE & 0.002 \\
\hline
\end{tabular}

\subsection{World Price Parameters}

For industrial roundwood, the parameters of the world price equation were estimated with panel data from 180 countries observed from 1992 to 2018, and a linear stochastic version of Equation (9):

$$
P_{i r t}=\vartheta_{i r}+\mu_{r} \ln Q_{i r t}+\pi_{r} \ln S_{i t}+\rho_{r} t+\varepsilon_{i r t} \forall i
$$

where $P_{i r t}$ was the price of industrial roundwood in country $i$ and year $t, Q_{i r t}$ was the production of industrial roundwood, $S_{i t}$ was the forest stock in country $i$ and year $t$, and $\varepsilon_{i r t}$ was a random error. The parameters of Equation (25) were estimated with fixed effects and two-stages least squares ([19] pp. 485-493 and 525-527), with the first stage a regression of production on GDP. The results in Table 4 show that the price of industrial roundwood was positively correlated to its production, negatively correlated to the growing stock, and decreased over time by $1 \%$ per year.

Table 4. Parameters of world price equations, by product.

\begin{tabular}{|c|c|c|c|c|c|}
\hline Product & $\begin{array}{l}\text { Dependent } \\
\text { Variable }\end{array}$ & $\begin{array}{c}\text { Independent } \\
\text { Variables }\end{array}$ & Coef. & SE & \\
\hline \multirow[t]{3}{*}{ Industrial roundwood } & \multirow[t]{3}{*}{$\ln P_{\text {irt }}$} & $\ln Q_{i r t}$ & 1.51 & 0.17 & ** \\
\hline & & $\ln S_{i t}$ & -0.38 & 0.08 & ** \\
\hline & & $t$ & -0.01 & 0.00 & ** \\
\hline Sawnwood & $\ln P_{\text {wst }}$ & $\ln P_{\text {wrt }}$ & 0.56 & 0.10 & ** \\
\hline Wood-based panels & $\ln P_{w l t}$ & $\ln P_{\text {wrt }}$ & 0.56 & 0.06 & ** \\
\hline Wood pulp & $\ln P_{\text {wut }}$ & $\ln P_{\text {wrt }}$ & 0.46 & 0.13 & ** \\
\hline Paper and paperboard & $\ln P_{\text {wat }}$ & $\ln P_{\text {wut }}$ & 0.65 & 0.10 & ** \\
\hline Fuelwood & $\ln P_{w f t}$ & $\ln P_{\text {wrt }}$ & 0.91 & 0.19 & ** \\
\hline
\end{tabular}

**: statistically significant at 0.01 level.

For sawnwood, wood-based panels, wood pulp, and fuelwood, the world price was estimated by ordinary least squares with a logarithmic form of Equation (10), and timeseries data on world prices from 1992 to 2018. For paper and paperboard a logarithmic form of Equation (11) was used instead. Table 4 shows that the elasticity of the world price of sawnwood, wood-based panels, wood pulp, and fuelwood with respect to the price of industrial roundwood ranged from $0.46( \pm 0.13)$ for wood pulp to $0.91( \pm 0.19)$ for fuelwood, while the elasticity of the world price of paper and paperboard with the price of wood pulp was $0.65( \pm 0.10)$. All elasticities were statistically significant at the 0.01 level. 


\subsection{Local Price Parameters}

The country-specific parameters of Equation (12) were obtained by minimizing the sum of the squares of the differences between the observed and predicted logarithm of local price, given the world price, for all products and countries, from 1992 to 2018:

Find the parameters $\tau_{i k}^{+}, \tau_{i k}^{-}, \alpha_{i k^{\prime}}^{+} \alpha_{i k}^{-} \geq 0 \forall i, k$;

such that:

$$
\min S S Q R=\sum_{i k t}\left(\ln P_{i k t}-\ln P_{w k t}\right)^{2}
$$

subject to:

$$
\begin{gathered}
\ln P_{i k t}=\tau_{i k} \ln P_{w k t}+\alpha_{i k} \quad \forall i, k, t \\
\tau_{i k}=\tau_{i k}^{+}-\tau_{i k}^{-} \quad \forall i, k \\
\alpha_{i k}=\alpha_{i k}^{+}-\alpha_{i k}^{-} \forall i, k
\end{gathered}
$$

The results summary (Table 5) shows that the mean price elasticity of the local price with respect to the world price, over all countries, varied from 0.43 for sawnwood to 1.08 for fuelwood. All mean values of the elasticities were statistically significant at least at the

\begin{tabular}{|c|c|c|c|c|c|}
\hline \multirow{2}{*}{$\frac{\text { Product }}{\text { Sawnwood }}$} & \multicolumn{2}{|c|}{ Elasticity } & \multirow{2}{*}{$\frac{\text { Product }}{\text { Wood pulp }}$} & \multicolumn{2}{|c|}{ Elasticity } \\
\hline & $\max$ & 4.11 & & $\max$ & 2.33 \\
\hline & $\min$ & -3.42 & & $\min$ & -0.85 \\
\hline & mean & 0.43 & & mean & 0.88 \\
\hline & SE & 0.08 & & SE & 0.03 \\
\hline \multirow[t]{4}{*}{ Wood-based panels } & $\max$ & 3.75 & Industrial roundwood & $\max$ & 2.83 \\
\hline & $\min$ & -3.31 & & $\min$ & -2.14 \\
\hline & mean & 1.03 & & mean & 0.81 \\
\hline & SE & 0.07 & & SE & 0.06 \\
\hline \multirow[t]{4}{*}{ Paper and paperboard } & $\max$ & 3.11 & Fuelwood & $\max$ & 3.43 \\
\hline & $\min$ & -2.16 & & $\min$ & -2.43 \\
\hline & mean & 0.83 & & mean & 1.08 \\
\hline & SE & 0.05 & & SE & 0.04 \\
\hline
\end{tabular}
0.01 level.

Table 5. Summary statistics of country-specific elasticity of local price with respect to world price $\left(\tau_{i k}\right)$ by product.

\subsection{Forest Area Parameters}

The parameters of the growth rate of forest area in Equation (14) were estimated by non-linear least squares with cross-sectional data from 186 countries on forest area growth rate and GDP per capita in 2017. With the GDP per capita $y_{i t}$ expressed in USD 1000 per person, the linear effect of GDP per capita on the forest growth rate was $\omega=0.0007$, with a standard error of 0.0001 , and the exponential effect was $\vartheta=-0.077$, with a standard error of 0.020 - both statistically significant at the 0.01 level.

\subsection{Forest Stock Parameters}

The country-specific parameters of the forest stock growth-drain Equation (15) were obtained by minimizing the sum of the squares of the difference between the observed and the predicted forest stock, with the following quadratic program:

Find the parameters $\sigma_{i}^{+}, \sigma_{i}^{-}, \alpha_{i} \geq 0 \forall i, k$;

such that:

$$
\min S S Q R_{i t}=\sum_{i t}\left(S_{i t}-\hat{S}_{i t}\right)^{2}
$$

subject to:

$$
\begin{gathered}
\hat{S}_{i t}=S_{i, t-1}\left(1+\sigma_{i}\right)-\alpha_{i}\left(Q_{i f, t-1}+Q_{i r, t-1}\right) \\
\sigma_{i}=\sigma_{i}^{+}-\sigma_{i}^{-} \quad \forall i, k
\end{gathered}
$$




$$
\alpha_{i} \leq \alpha_{i}^{U} \forall i, k
$$

where $\alpha_{i}^{U}$ is an a priori upper bound on the impact of the harvest on forest growth.

The results in Table 6 show a mean value of the annual growth rate of forest stock without harvest $\bar{\sigma}=0.009$, and a mean value of the harvest effect $\bar{\alpha}=0.39$ (with harvest and stock in million $\mathrm{m}^{3}$ )—both statistically significant at least at the 0.01 level.

Table 6. Summary statistics of country-specific stock growth parameters.

\begin{tabular}{ccc}
\hline & Growth Rate without Harvest, $\sigma_{i}$ & Harvest Effect, $\alpha_{i}$ \\
\hline $\max$ & 0.114 & 1.20 \\
$\min$ & -0.034 & 0.00 \\
mean & 0.009 & 0.39 \\
SE & 0.001 & 0.03 \\
\hline
\end{tabular}

\subsection{Base Year Calibration}

The GFPMX formulae automatically calibrate all constant terms in Equations (1)-(14) so that the calculated value in the base year matches the observations in that year. For example, in Equation (1), with base year 2018, the calibrated value of the constant $\alpha_{i k}$ is:

$$
\hat{\alpha}_{i k}=C_{i k, 2018} P_{i k, 2017}^{-\beta_{i k}} Y_{i, 2018}^{-\gamma_{i k}} \forall k=f, s, l, a
$$

\section{Computer Implementation}

The GFPMX software, written by the author, consists of a workbook of multiple spreadsheets in Microsoft Excel ${ }^{\circledR}$ (2016). The spreadsheets are macro free. Potential users have control of the basic data for 180 countries. The spreadsheets accommodate 26 years of historical data, currently from 1992 to 2018 . The projected years, currently up to 2070, are at the users' discretion, as are the parameters and formulae. Once the program has been uploaded, long-term projections with new data or assumptions are nearly instantaneous. The current version of the GFPMX with the data and parameters described above, and used in the following application to the impact of the COVID-19 pandemic, is available at: https:/ /buongiorno.russell.wisc.edu/gfpm/ (accessed on 5 May 2021). The GFPMX software, data, and model formulation are also available as supplementary material for this paper.

\section{Application to the Effect of the COVID-19 Recession on the Global Forest Sector 5.1. Exogenous Projections of the Effect of the COVID-19 on Economic Growth}

Table 7 summarizes the International Monetary Fund's projections of GDP growth before the COVID-19 pandemic, published in January 2020 [20], and the revised projections of January 2021 [21]. The projection of the world output for 2020 went from 3.3 percent before the COVID-19 pandemic to -3.5 percent, a contraction of 6.8 percentage points. The contractions for France, Spain, and the United Kingdom exceeded ten percentage points. The growth rates for 2020 were negative for most regions and countries. The only exception was China, projected to grow at 2.3 percent per year in 2020-still less than the pre-COVID-19 projection by 3.7 percentage points. The IMF projections for 2021 suggested a recovery in all countries, but still not enough to compensate for the 2020 contraction. Globally, world output would increase by 5.5 percent in 2021 , short of the $6.8 \%$ contraction in 2020 relative to the pre-COVID-19 projection.

To estimate the consequences of these projections on the global forest sector, the data in Table 7 were introduced in the GFPMX to simulate two scenarios. A base scenario assumed the pre-COVID-19 growth rates for 2019, 2020, and 2021. The alternative scenario assumed the same GDP growth rates as the base scenario for 2019, and the post-COVID-19 growth rates in Table 7 for 2020 and 2021. To assess the long-term ceteris paribus impact of the COVID-19 recession, the simulations were continued up to the year 2030. In both scenarios the assumed GDP growth from 2022 to 2030, and the assumed population growth 
from 1999 to 2030, corresponded to the SSP2 scenario—an intermediate scenario among the five demographic and economic scenarios of the Shared Socioeconomic Pathways [22,23].

Table 7. Pre- and post-COVID-2019 International Monetary Fund projections of GDP growth in 2020 and 2021.

\begin{tabular}{|c|c|c|c|c|c|}
\hline \multirow[b]{2}{*}{ Country/Region } & \multirow{2}{*}{$\begin{array}{c}\text { Estimate }^{2} \\
2019\end{array}$} & \multicolumn{2}{|c|}{$\begin{array}{c}\text { Projection } \\
\text { Pre-COVID-19 } 1\end{array}$} & \multicolumn{2}{|c|}{$\begin{array}{c}\text { Projection } \\
\text { Post-COVID-19 }\end{array}$} \\
\hline & & 2020 & 2021 & 2020 & 2021 \\
\hline World output & 2.8 & 3.3 & 3.4 & -3.5 & 5.5 \\
\hline Advanced economies & 1.6 & 1.6 & 1.6 & -4.9 & 4.3 \\
\hline United States & 2.2 & 2 & 1.7 & -3.4 & 5.1 \\
\hline Euro Area & 1.3 & 1.3 & 1.4 & -7.2 & 4.2 \\
\hline Germany & 0.6 & 1.1 & 1.4 & -5.4 & 3.5 \\
\hline France & 1.5 & 1.3 & 1.3 & -9.0 & 5.5 \\
\hline Italy & 0.3 & 0.5 & 0.7 & -9.2 & 3.0 \\
\hline Spain & 2.0 & 1.6 & 1.6 & -11.1 & 5.9 \\
\hline Japan & 0.3 & 0.7 & 0.5 & -5.1 & 3.1 \\
\hline United Kingdom & 1.4 & 1.4 & 1.5 & -10.0 & 4.5 \\
\hline Canada & 1.9 & 1.8 & 1.8 & -5.5 & 3.6 \\
\hline Other advanced economies & 1.8 & 1.9 & 2.4 & -2.5 & 3.6 \\
\hline $\begin{array}{l}\text { Emerging market and } \\
\text { developing economies }\end{array}$ & 3.6 & 4.4 & 4.6 & -2.4 & 6.3 \\
\hline $\begin{array}{l}\text { Emerging and developing } \\
\text { Asia }\end{array}$ & 5.4 & 5.8 & 5.9 & -1.1 & 8.3 \\
\hline China & 6.0 & 6 & 5.8 & 2.3 & 8.1 \\
\hline India & 4.2 & 5.8 & 6.5 & -8.0 & 11.5 \\
\hline ASEAN-5 & 4.9 & 4.8 & 5.1 & -3.7 & 5.2 \\
\hline $\begin{array}{l}\text { Emerging and developing } \\
\text { Europe }\end{array}$ & 2.2 & 2.6 & 2.5 & -2.8 & 4.0 \\
\hline Russia & 1.3 & 1.9 & 2 & -3.6 & 3.0 \\
\hline $\begin{array}{l}\text { Latin America and the } \\
\text { Caribbean }\end{array}$ & 0.2 & 1.6 & 2.3 & -7.4 & 4.1 \\
\hline Brazil & 1.4 & 2.2 & 2.3 & -4.5 & 3.6 \\
\hline Mexico & -0.1 & 1 & 1.6 & -8.5 & 4.3 \\
\hline Middle East and Central Asia & 1.4 & 2.8 & 3.2 & -3.2 & 3.0 \\
\hline Saudi Arabia & 0.3 & 1.9 & 2.2 & -3.9 & 2.6 \\
\hline Sub-Saharan Africa & 3.2 & 3.5 & 3.5 & -2.6 & 3.2 \\
\hline Nigeria & 2.2 & 2.5 & 2.5 & -3.2 & 1.5 \\
\hline South Africa & 0.2 & 0.8 & 1 & -7.5 & 2.8 \\
\hline
\end{tabular}

${ }^{1}$ IMF 2020; ${ }^{2}$ IMF 2021.

\subsection{Effects on Roundwood Production and Trade}

According to the GFPMX projections, the economic recession due to the COVID-19 pandemic reduced the world production of roundwood (industrial roundwood and fuelwood) by 40.8 million $\mathrm{m}^{3}(-1 \%)$ in 2020 (Table 8 ). Despite the projected partial economic recovery in 2021, the world production of roundwood in 2021 was still 19 million $\mathrm{m}^{3}$ less $(-0.5 \%)$ with the COVID-19 recession than without it. COVID-19's impact increased further to -38 million $\mathrm{m}^{3}(-0.9 \%)$ by 2030 . The largest regional effects were in Europe ( -22.8 million $\mathrm{m}^{3}$, or $-2.8 \%$ in 2020) and in South America ( -7.9 million $\mathrm{m}^{3}$, or $\left.-2.0 \%\right)$. At the national level, in 2020, production decreased the most in Russia (-7.9 million $\mathrm{m}^{3}$, or $-3.3 \%)$, India ( -3.7 million $\mathrm{m}^{3}$, or $\left.-1 \%\right)$, and Brazil ( -3.3 million $\mathrm{m}^{3}$, or $-1.3 \%$ ). However, production was higher in the COVID-19 scenario in DR Congo, the United States, and Indonesia.

The world imports of roundwood were 3.9 million $\mathrm{m}^{3}$ lower $(-1.7 \%)$ in 2020 due to the COVID-19 recession (Table 8). Asia was by far the most affected region, in large part due to lower imports in China ( -2.4 million $\mathrm{m}^{3}$, or $-2.9 \%$ in 2020) and Japan $\left(-793,000 \mathrm{~m}^{3}\right.$, or $-3.2 \%$ ). In 2021, world imports exceeded what they would have been without the 
COVID-19, due mostly to China's imports. But, by 2030 the projected world roundwood imports were still $687,000 \mathrm{~m}^{3}$ less than they would have been without the COVID-19 recession. The effects were nil or negligible on imports in South America, Oceania, and North America.

Table 8. Effect of the COVID-19 economic recession on roundwood production, import, and export in 2020, 2021, and 2030, by region, and in the ten most affected countries in 2020 .

\begin{tabular}{|c|c|c|c|c|c|c|c|c|c|c|c|}
\hline \multirow{2}{*}{$\begin{array}{l}\text { Region/ } \\
\text { Country }\end{array}$} & \multicolumn{3}{|c|}{ Production $\left(1000 \mathrm{~m}^{3}\right)$} & \multirow{2}{*}{$\begin{array}{l}\text { Region/ } \\
\text { Country }\end{array}$} & \multicolumn{3}{|c|}{ Import $\left(1000 \mathrm{~m}^{3}\right)$} & \multirow{2}{*}{$\begin{array}{l}\text { Region/ } \\
\text { Country }\end{array}$} & \multicolumn{3}{|c|}{ Export $\left(1000 \mathrm{~m}^{3}\right)$} \\
\hline & 2020 & 2021 & 2030 & & 2020 & 2021 & 2030 & & 2020 & 2021 & 2030 \\
\hline WORLD $^{1}$ & $-40,835$ & $-19,231$ & $-37,951$ & WORLD $^{1}$ & -3943 & 320 & -687 & WORLD $^{1}$ & -4049 & 353 & -710 \\
\hline AFRICA & -5118 & -3357 & $-10,693$ & AFRICA & -66 & -42 & -73 & AFRICA & -204 & 0 & -53 \\
\hline $\begin{array}{c}\text { N. } \\
\text { AMERICA }\end{array}$ & 107 & 532 & -306 & $\begin{array}{c}\text { N. } \\
\text { AMERICA }\end{array}$ & -15 & 16 & 0 & $\begin{array}{c}\text { N. } \\
\text { AMERICA }\end{array}$ & -97 & 11 & -15 \\
\hline $\begin{array}{c}\text { S. } \\
\text { AMERICA }\end{array}$ & -7913 & -3776 & -5814 & $\begin{array}{c}\text { S. } \\
\text { AMERICA }\end{array}$ & 0 & 0 & 0 & $\begin{array}{c}\text { S. } \\
\text { AMERICA }\end{array}$ & -170 & 28 & -16 \\
\hline ASIA & -4131 & -3219 & -4780 & ASIA & -3244 & 572 & -199 & ASIA & -367 & 75 & -45 \\
\hline OCEANIA & -985 & 149 & -138 & OCEANIA & 0 & 3 & 0 & OCEANIA & -864 & 138 & -84 \\
\hline EUROPE & $-22,795$ & -9560 & $-16,220$ & EUROPE & -617 & -229 & -416 & EUROPE & -2345 & 101 & -498 \\
\hline Russia & -7922 & -2314 & -4757 & China & -2431 & 797 & 149 & Russia & -546 & 100 & -40 \\
\hline India & -3741 & -1905 & -2265 & Japan & -793 & -385 & -431 & Vietnam & -448 & 73 & -42 \\
\hline Brazil & -3302 & -1012 & -2135 & Luxembourg & -133 & -15 & -50 & $\begin{array}{c}\text { New } \\
\text { Zealand }\end{array}$ & -423 & 69 & -39 \\
\hline Germany & -2547 & -1449 & -1918 & Italy & -106 & -81 & -114 & Australia & -332 & 51 & -34 \\
\hline Chile & -2434 & -1583 & -2028 & Slovakia & -97 & -62 & -76 & Ukraine & -199 & -42 & -92 \\
\hline Poland & -1646 & -907 & -1216 & Czech Rep. & -67 & -34 & -56 & Canada & -200 & 42 & -10 \\
\hline Finland & -1516 & -853 & -1199 & $\begin{array}{l}\text { South } \\
\text { Africa }\end{array}$ & -59 & -38 & -55 & Latvia & -162 & 24 & -18 \\
\hline Indonesia & 1431 & 1012 & 872 & Austria & -47 & -30 & -34 & Czech Rep. & -132 & 20 & -14 \\
\hline $\begin{array}{l}\text { United } \\
\text { States }\end{array}$ & 2247 & 1524 & 1179 & Germany & -28 & -12 & -15 & Thailand & -129 & 21 & -12 \\
\hline Congo, DR & 4935 & 5111 & 1467 & Greece & -24 & -16 & -21 & Malaysia & 227 & -37 & 21 \\
\hline
\end{tabular}

${ }^{1}$ World import may differ from world export due to differences in base year statistics.

For exports, the regions most affected by the COVID-19 recession were Europewhere exports decreased by 2.3 million $\mathrm{m}^{3}(-2.4 \%)$ in 2020 -and Oceania $\left(-864,000 \mathrm{~m}^{3}\right.$, or $-1.7 \%$ in 2020). Russia, Vietnam, and New Zealand had the largest national decreases in roundwood exports. The general recovery of 2021 led to global exports that exceeded what they would have been without the COVID-19 recession. Still, by 2030, exports were below what they would have been without the COVID-19, in all regions and countries in Table 8 except Malaysia.

It may be noted that the slight difference between the impact on world imports and exports in Table 8 and succeeding tables is due to differences in world import and export statistics for the base year, here 2018.

\subsection{Effects on Sawnwood Production and Trade}

The economic recession caused by the COVID-19 pandemic reduced the world production of sawnwood by 8.7 million $\mathrm{m}^{3}(1.7 \%)$ in 2020 (Table 9$)$. The largest regional reductions were in Europe $\left(-4\right.$ million $\mathrm{m}^{3}$, or $\left.-2.3 \%\right)$ and Asia (-3.4 million $\mathrm{m}^{3}$, or $\left.-2.3 \%\right)$. Among individual countries, sawnwood production was reduced the most in China $\left(-1.9\right.$ million $\mathrm{m}^{3}$, or $-2 \%$ ) and Russia ( -1.5 million $\mathrm{m}^{3}$, or $-3.4 \%$ ) in 2020 . Although the projected partial economic recovery in 2021 reduced the impact of the COVID-19 recession, world sawnwood production was still 4.8 million $\mathrm{m}^{3}(0.9 \%)$ less in 2021 than it would have been without the COVID-19, and the difference increased further to -7.3 million $\mathrm{m}^{3}(-1.2 \%)$ by 2030 .

In 2020, global world sawnwood imports were projected to be 4.5 million $\mathrm{m}^{3}(2.9 \%)$ lower due to the COVID-19 recession (Table 9). In absolute terms, imports in Asia were the most affected ( -2.6 million $\mathrm{m}^{3}$, or $-3.8 \%$ in 2020 , of which nearly half was in China), followed by the reduction of imports in Europe $\left(-1.2\right.$ million $\mathrm{m}^{3}$, or $\left.-28 \%\right)$. In 2021 the projected world imports of sawnwood were still 2.4 million $\mathrm{m}^{3}$ less $(-1.5 \%)$ than 
they would have been without the COVID-19 recession-a difference that increased to 3.7 million $\mathrm{m}^{3}(-1.9 \%)$ by 2030 . In contrast, the consequences of COVID-19 were negligible or small for imports in South America and Oceania.

Table 9. Effect of the COVID-19 economic recession on sawnwood production, import, and export in 2020, 2021, and 2030, by region, and in the ten most affected countries in 2020 .

\begin{tabular}{|c|c|c|c|c|c|c|c|c|c|c|c|}
\hline \multirow{2}{*}{$\begin{array}{l}\text { Region/ } \\
\text { Country }\end{array}$} & \multicolumn{3}{|c|}{ Production $\left(1000 \mathrm{~m}^{3}\right)$} & \multirow{2}{*}{$\begin{array}{l}\text { Region/ } \\
\text { Country }\end{array}$} & \multicolumn{3}{|c|}{ Import $\left(1000 \mathrm{~m}^{3}\right)$} & \multirow{2}{*}{$\begin{array}{l}\text { Region/ } \\
\text { Country }\end{array}$} & \multicolumn{3}{|c|}{ Export $\left(1000 \mathrm{~m}^{3}\right)$} \\
\hline & 2020 & 2021 & 2030 & & 2020 & 2021 & 2030 & & 2020 & 2021 & 2030 \\
\hline WORLD $^{1}$ & -8671 & -4804 & -7253 & WORLD $^{1}$ & -4450 & -2369 & -3682 & WORLD $^{1}$ & -4488 & -2420 & -3795 \\
\hline AFRICA & -191 & -146 & -252 & AFRICA & -482 & -452 & -603 & AFRICA & -72 & -41 & -87 \\
\hline $\begin{array}{c}\text { N. } \\
\text { AMERICA }\end{array}$ & -164 & 115 & -14 & $\begin{array}{c}\text { N. } \\
\text { AMERICA }\end{array}$ & -155 & -82 & -120 & $\begin{array}{c}\text { N. } \\
\text { AMERICA }\end{array}$ & -176 & -107 & -168 \\
\hline $\begin{array}{c}\text { S. } \\
\text { AMERICA }\end{array}$ & -807 & -539 & -746 & $\begin{array}{c}\text { S. } \\
\text { AMERICA }\end{array}$ & -30 & -22 & -30 & $\begin{array}{c}\text { S. } \\
\text { AMERICA }\end{array}$ & -322 & -181 & -287 \\
\hline ASIA & -3357 & -2095 & -2896 & ASIA & -2579 & -1103 & -2007 & ASIA & -210 & -117 & -182 \\
\hline OCEANIA & -147 & -82 & -125 & OCEANIA & -5 & -2 & -4 & OCEANIA & -83 & -44 & -69 \\
\hline EUROPE & -4004 & -2056 & -3220 & EUROPE & -1200 & -707 & -918 & EUROPE & -3626 & -1930 & -3002 \\
\hline China & -1884 & -979 & -1222 & China & -1207 & -211 & -482 & Russia & -1487 & -792 & -1231 \\
\hline Russia & -1487 & -785 & -1226 & Japan & -371 & -209 & -220 & Germany & -494 & -263 & -409 \\
\hline Japan & -555 & -313 & -331 & Egypt & -222 & -230 & -304 & Thailand & -265 & -141 & -219 \\
\hline Germany & -546 & -228 & -400 & Austria & -172 & -106 & -119 & Ukraine & -192 & -102 & -158 \\
\hline Vietnam & -498 & -492 & -933 & France & -162 & -73 & -98 & Chile & -182 & -97 & -151 \\
\hline Chile & -355 & -232 & -300 & Belgium & -156 & -111 & -154 & Sweden & -180 & -96 & -149 \\
\hline Thailand & -350 & -228 & -324 & Vietnam & -144 & -143 & -272 & Canada & -160 & -85 & -132 \\
\hline Sweden & -321 & -161 & -242 & Uzbekistan & -139 & -23 & -175 & Latvia & -153 & -82 & -127 \\
\hline Latvia & -203 & -117 & -171 & Estonia & -129 & -92 & -108 & Belarus & -150 & -80 & -124 \\
\hline Ukraine & -192 & -102 & -158 & Algeria & -117 & -103 & -136 & Finland & -146 & -78 & -121 \\
\hline
\end{tabular}

${ }^{1}$ World import differs from world export due to differences in base year statistics.

For sawnwood exports, COVID-19's impact was largest in absolute value in Europe, at -3.6 million $\mathrm{m}^{3}(-3.6 \%)$ in 2020 , reduced to -1.9 million $\mathrm{m}^{3}(-1.9 \%)$ in 2021 , but rising again to -3.0 million $\mathrm{m}^{3}(-2.2 \%)$ by 2030 . At the national level, the largest export losses were in Russia ( -1.5 million $\mathrm{m}^{3}$, or $-4.5 \%$ in 2020 ) and Germany (Table 9).

\subsection{Effects on Wood-Based Panels Production and Trade}

Due to the COVID-19 recession, the world production of wood-based panels projected with the GFPMX dropped by 15.5 million $\mathrm{m}^{3}$ (-3.6\%) in 2020 compared to what it would have been without the pandemic (Table 10). Despite the partial economic recovery in 2021, world production was still 7.0 million $\mathrm{m}^{3}$ less in 2021 than it would have been with the pre-COVID-19 economic growth projected by the International Monetary Fund. The difference at the global level increased further to -11.5 million $\mathrm{m}^{3}(-1.9 \%)$ in 2030 . The two most affected regions were Asia and Europe, and specifically China $\left(-8.3\right.$ million $\mathrm{m}^{3}$, or $-4 \%$ in 2020$)$ and Russia $\left(-920,000 \mathrm{~m}^{3}\right.$, or $-4.9 \%$ in 2020$)$.

World imports of wood-based panels were 5.3 million $\mathrm{m}^{3}$ less $(-5.4 \%)$ in 2020 with the COVID-19 scenario than with the base scenario. In 2021, world production was still 3.0 million $\mathrm{m}^{3}$ less $(-3.1 \%)$ due to the COVID-19 recession, and the difference increased to -4.5 million $\mathrm{m}^{3}(-3.7 \%)$ by 2030 . Europe, Asia, and North America experienced the largest reductions of imports. The United States was the country with the largest contraction in $2020\left(-940,000 \mathrm{~m}^{3}\right)$, but reduced to $-291,000 \mathrm{~m}^{3}$ by 2030 .

The largest regional impacts of the COVID-19 recession on exports of wood-based panels were in Europe (-3.0 million $\mathrm{m}^{3}$, or $-6.4 \%$ in 2020)-mostly in Germany and Russia-and in Asia (-1.5 million $\mathrm{m}^{3}$, or $-5 \%$ in 2020), principally in China (Table 10).

\subsection{Effects on Wood Pulp Production and Trade}

As summarized in Table 11, the world production of wood pulp was reduced by 3.5 million $\mathrm{t}(1.9 \%)$ in 2020 , due to the COVID-19 recession. This reduction was mostly in Asia ( -1.4 million $t$, or $-3.5 \%)$, South America ( -1.0 million $t$, or $-3.6 \%$ ), and Europe $(-1.0$ million $t$, or $-2.2 \%)$. The countries most affected in absolute terms in 2020 were 
Brazil $(-704,000 \mathrm{t}$, or $-3.5 \%)$, India $(-425,000 \mathrm{t}$, or $-12.4 \%)$, and Indonesia $(-406,000 \mathrm{t}$, or $-4.8 \%$ ). Although the impact was less in 2021 than in 2020, global wood pulp production was still 2.2 million $t$ less $(-1.2 \%)$ with the COVID-19 scenario than with the base scenario. Subsequently, this difference increasede, reaching -3.4 million $t$, or $-1.6 \%$ in 2030 .

Table 10. Effect of the COVID-19 economic recession on wood-based panels production, import, and export in 2020, 2021 and 2030, by region, and in the ten most affected countries in 2020.

\begin{tabular}{|c|c|c|c|c|c|c|c|c|c|c|c|}
\hline \multirow{2}{*}{$\begin{array}{l}\text { Region/ } \\
\text { Country }\end{array}$} & \multicolumn{3}{|c|}{ Production $\left(1000 \mathrm{~m}^{3}\right)$} & \multirow{2}{*}{$\begin{array}{l}\text { Region/ } \\
\text { Country }\end{array}$} & \multicolumn{3}{|c|}{ Import $\left(1000 \mathrm{~m}^{3}\right)$} & \multirow{2}{*}{$\begin{array}{l}\text { Region/ } \\
\text { Country }\end{array}$} & \multicolumn{3}{|c|}{ Export $\left(1000 \mathrm{~m}^{3}\right)$} \\
\hline & 2020 & 2021 & 2030 & & 2020 & 2021 & 2030 & & 2020 & 2021 & 2030 \\
\hline WORLD $^{1}$ & $-15,475$ & -6970 & $-11,502$ & WORLD $^{1}$ & -5288 & -3049 & -4456 & WORLD $^{1}$ & -5290 & -3053 & -4500 \\
\hline AFRICA & -139 & -105 & -160 & AFRICA & -153 & -140 & -207 & AFRICA & -33 & -19 & -30 \\
\hline $\begin{array}{c}\text { N. } \\
\text { AMERICA }\end{array}$ & 224 & 29 & -99 & $\begin{array}{c}\text { N. } \\
\text { AMERICA }\end{array}$ & -1319 & -449 & -656 & $\begin{array}{c}\text { N. } \\
\text { AMERICA }\end{array}$ & -235 & -136 & -199 \\
\hline $\begin{array}{c}\text { S. } \\
\text { AMERICA }\end{array}$ & -1293 & -751 & -1094 & $\begin{array}{c}\text { S. } \\
\text { AMERICA }\end{array}$ & -183 & -152 & -200 & $\begin{array}{c}\text { S. } \\
\text { AMERICA }\end{array}$ & -398 & -230 & -346 \\
\hline ASIA & $-10,207$ & -3721 & -6728 & ASIA & -1373 & -957 & -1599 & ASIA & -1540 & -889 & -1326 \\
\hline OCEANIA & -104 & -53 & -76 & OCEANIA & -36 & -20 & -29 & OCEANIA & -50 & -29 & -43 \\
\hline EUROPE & -3956 & -2368 & -3345 & EUROPE & -2224 & -1332 & -1764 & EUROPE & -3034 & -1749 & -2556 \\
\hline China & -8323 & -2329 & -4507 & $\begin{array}{l}\text { United } \\
\text { States }\end{array}$ & -940 & -173 & -291 & China & -1364 & -787 & -1149 \\
\hline Russia & -920 & -604 & -791 & Germany & -319 & -187 & -203 & Germany & -512 & -295 & -431 \\
\hline Brazil & -724 & -335 & -523 & France & -255 & -133 & -191 & Thailand & -419 & -242 & -353 \\
\hline Poland & -693 & -399 & -570 & Italy & -267 & -177 & -256 & Russia & -391 & -225 & -329 \\
\hline Thailand & -571 & -372 & -528 & Canada & -219 & -153 & -201 & Canada & -329 & -190 & -277 \\
\hline Turkey & -552 & -395 & -532 & Poland & -203 & -115 & -163 & Belgium & -263 & -152 & -222 \\
\hline Canada & -547 & -366 & -483 & Japan & -170 & -80 & -88 & Poland & -248 & -143 & -209 \\
\hline India & -452 & -335 & -651 & Belgium & -136 & -74 & -111 & Brazil & -224 & -129 & -188 \\
\hline Chile & -293 & -215 & -284 & India & -137 & -94 & -186 & Romania & -215 & -124 & -181 \\
\hline Belarus & -252 & -150 & -208 & Mexico & -125 & -95 & -129 & Indonesia & 621 & 358 & 523 \\
\hline
\end{tabular}

${ }^{1}$ World import differs from world export due to differences in base year statistics.

Table 11. Effect of the COVID-19 economic recession on wood pulp production, import, and export in 2020, 2021, and 2030, by region and in the ten most affected countries in 2020 .

\begin{tabular}{|c|c|c|c|c|c|c|c|c|c|c|c|}
\hline \multirow{2}{*}{$\begin{array}{l}\text { Region/ } \\
\text { Country }\end{array}$} & \multicolumn{3}{|c|}{ Production $(1000 \mathrm{t})$} & \multirow{2}{*}{$\begin{array}{l}\text { Region/ } \\
\text { Country }\end{array}$} & \multicolumn{3}{|c|}{ Import (1000 t) } & \multirow{2}{*}{$\begin{array}{l}\text { Region/ } \\
\text { Country }\end{array}$} & \multicolumn{3}{|c|}{ Export $(1000 t)$} \\
\hline & 2020 & 2021 & 2030 & & 2020 & 2021 & 2030 & & 2020 & 2021 & 2030 \\
\hline WORLD $^{1}$ & -3524 & -2244 & -3350 & WORLD $^{1}$ & -1332 & -587 & -958 & WORLD $^{1}$ & -1331 & -587 & -978 \\
\hline AFRICA & -2 & -8 & -2 & AFRICA & -8 & -4 & -16 & AFRICA & 19 & 8 & 4 \\
\hline $\begin{array}{c}\text { N. } \\
\text { AMERICA }\end{array}$ & -65 & 45 & 4 & $\begin{array}{c}\text { N. } \\
\text { AMERICA }\end{array}$ & -96 & -49 & -78 & $\begin{array}{c}\text { N. } \\
\text { AMERICA }\end{array}$ & -27 & -12 & -20 \\
\hline $\begin{array}{c}\text { S. } \\
\text { AMERICA }\end{array}$ & -1024 & -518 & -774 & $\begin{array}{c}\text { S. } \\
\text { AMERICA }\end{array}$ & -24 & -17 & -22 & $\begin{array}{c}\text { S. } \\
\text { AMERICA }\end{array}$ & -789 & -348 & -567 \\
\hline ASIA & -1379 & -1087 & -1583 & ASIA & -769 & -227 & -442 & ASIA & -198 & -88 & -143 \\
\hline OCEANIA & -31 & -19 & -26 & OCEANIA & -7 & -3 & -6 & OCEANIA & -13 & -6 & -9 \\
\hline EUROPE & -1023 & -657 & -970 & EUROPE & -427 & -287 & -394 & EUROPE & -322 & -142 & -242 \\
\hline Brazil & -704 & -365 & -537 & China & -466 & -11 & -112 & Brazil & -515 & -227 & -370 \\
\hline India & -425 & -309 & -603 & India & -105 & -76 & -141 & Chile & -161 & -71 & -116 \\
\hline Indonesia & -406 & -279 & -399 & Belgium & -106 & -79 & -105 & Indonesia & -156 & -69 & -112 \\
\hline Russia & -311 & -204 & -271 & Germany & -92 & -62 & -82 & Uruguay & -113 & -50 & -81 \\
\hline $\begin{array}{l}\text { United } \\
\text { States }\end{array}$ & -281 & -104 & -210 & Mexico & -82 & -60 & -81 & $\begin{array}{l}\text { United } \\
\text { States }\end{array}$ & -87 & -38 & -62 \\
\hline China & -242 & -272 & -267 & Poland & -73 & -52 & -71 & Finland & -86 & -38 & -62 \\
\hline Finland & -220 & -134 & -199 & Spain & -56 & -39 & -50 & Russia & -58 & -26 & -42 \\
\hline Chile & -189 & -91 & -141 & Italy & -44 & -26 & -32 & Germany & -49 & -22 & -35 \\
\hline Sweden & -133 & -92 & -125 & Turkey & -41 & -30 & -37 & Netherlands & -47 & -21 & -34 \\
\hline Canada & 236 & 165 & 237 & $\begin{array}{c}\text { Korea, } \\
\text { Rep. }\end{array}$ & -38 & -25 & -30 & Canada & 59 & 26 & 43 \\
\hline
\end{tabular}

${ }^{1}$ World import differs from world export due to differences in base year statistics.

In the COVID-19 recession scenario, the world imports of wood pulp were 1.3 million $t$, or $2.3 \%$ less in 2020 than in the base scenario. Despite the 2021 recovery, imports were still $587,000 \mathrm{t}(1.5 \%)$ less in 2021, and 958,000 $\mathrm{t}$ less in 2030. The largest decreases of imports in 
2020 were in Asia $(-769,000 \mathrm{t}$, or $-2.4 \%)$ and Europe $(-427,000 \mathrm{t}$, or $-2.3 \%)$. China, India, and Belgium were the countries with the largest reductions of imports.

Exports of wood pulp were reduced the most in South America $(-789,000 \mathrm{t}$, or $-3.8 \%$ in 2020), Europe $(-322,000 \mathrm{t}$, or $-2.1 \%)$, and Asia $(-198,000 \mathrm{t}$, or $-3.8 \%)$. For individual countries, the largest national reductions of exports in 2020 were in Brazil $(-515,000 t$, or $-3.7 \%)$, Chile $(-161,000 \mathrm{t}$, or $-3.6 \%)$, and Indonesia $(-156,000 \mathrm{t}$, or $-4.1 \%)$.

\subsection{Effects on Paper and Paperboard Production and Trade}

According to the GFPMX simulations, the economic recession caused by the COVID-19 pandemic reduced world production of paper and paperboard by 11.8 million $t(-2.8 \%)$ in 2020 (Table 12). Although the economic recovery projected in 2021 narrowed the difference, wood pulp production was still 8.0 million $t$ less $(-1.9 \%)$ in the COVID-19 scenario, and the difference increased to 12 million $\mathrm{t}(-2.3 \%)$ by 2030 . The two most affected regions were Asia ( -7.4 million $t$, or $-3.6 \%$ in 2020$)$, and Europe ( -3.3 million $t$, or $-3.1 \%)$. At the national level, China's production was reduced the most due to the COVID-19 recession $(-2.6$ million $t$, or $-2.2 \%$ in 2020$)$, followed by India $(-2.4$ million $t$, or $-12.4 \%)$ and Germany $(-887,000 \mathrm{t}$, or $-3.9 \%)$.

Table 12. Effect of the COVID-19 economic recession on paper and paperboard production, import, and export in 2020, 2021, and 2030, by region, and in the ten most affected countries in 2020.

\begin{tabular}{|c|c|c|c|c|c|c|c|c|c|c|c|}
\hline \multirow{2}{*}{$\begin{array}{l}\text { Region/ } \\
\text { Country }\end{array}$} & \multicolumn{3}{|c|}{ Production (1000 $t)$} & \multirow{2}{*}{$\begin{array}{l}\text { Region/ } \\
\text { Country }\end{array}$} & \multicolumn{3}{|c|}{ Import (1000 t) } & \multirow{2}{*}{$\begin{array}{l}\text { Region/ } \\
\text { Country }\end{array}$} & \multicolumn{3}{|c|}{ Export (1000 t) } \\
\hline & 2020 & 2021 & 2030 & & 2020 & 2021 & 2030 & & 2020 & 2021 & 2030 \\
\hline WORLD ${ }^{1}$ & $-11,761$ & -7966 & $-11,809$ & WORLD $^{1}$ & -4753 & -3395 & -4753 & WORLD $^{1}$ & -4751 & -3394 & -4763 \\
\hline AFRICA & -46 & -37 & -64 & AFRICA & -310 & -282 & -394 & AFRICA & -44 & -32 & -45 \\
\hline $\begin{array}{c}\text { N. } \\
\text { AMERICA }\end{array}$ & -464 & -337 & -478 & $\begin{array}{c}\text { N. } \\
\text { AMERICA }\end{array}$ & -584 & -419 & -557 & $\begin{array}{c}\text { N. } \\
\text { AMERICA }\end{array}$ & 24 & 17 & 23 \\
\hline $\begin{array}{c}\text { S. } \\
\text { AMERICA }\end{array}$ & -531 & -397 & -492 & $\begin{array}{c}\text { S. } \\
\text { AMERICA }\end{array}$ & -185 & -147 & -180 & $\begin{array}{c}\text { S. } \\
\text { AMERICA }\end{array}$ & -144 & -103 & -154 \\
\hline ASIA & -7362 & -4761 & -7426 & ASIA & -1503 & -1186 & -1901 & ASIA & -1273 & -910 & -1274 \\
\hline OCEANIA & -84 & -62 & -86 & OCEANIA & -21 & -10 & -13 & OCEANIA & -90 & -64 & -90 \\
\hline EUROPE & -3275 & -2373 & -3262 & EUROPE & -2151 & -1350 & -1707 & EUROPE & -3223 & -2302 & -3223 \\
\hline China & -2625 & -1135 & -1531 & India & -465 & -324 & -640 & Germany & -859 & -613 & -859 \\
\hline India & -2366 & -1728 & -3355 & Mexico & -391 & -280 & -384 & Belgium & -370 & -265 & -370 \\
\hline Germany & -887 & -633 & -878 & Germany & -344 & -174 & -199 & China & -358 & -256 & -358 \\
\hline Indonesia & -670 & -572 & -807 & Italy & -333 & -231 & -296 & $\begin{array}{l}\text { United } \\
\text { States }\end{array}$ & -319 & -228 & -319 \\
\hline $\begin{array}{l}\text { Mexico } \\
\text { Thailand }\end{array}$ & $\begin{array}{l}-539 \\
-383\end{array}$ & $\begin{array}{l}-403 \\
-345\end{array}$ & $\begin{array}{l}-548 \\
-445\end{array}$ & $\begin{array}{l}\text { Belgium } \\
\text { Poland }\end{array}$ & $\begin{array}{l}-284 \\
-232\end{array}$ & $\begin{array}{l}-176 \\
-166\end{array}$ & $\begin{array}{l}-254 \\
-217\end{array}$ & $\begin{array}{l}\text { Indonesia } \\
\text { Sweden }\end{array}$ & $\begin{array}{l}-318 \\
-305\end{array}$ & $\begin{array}{l}-227 \\
-218\end{array}$ & $\begin{array}{l}-318 \\
-306\end{array}$ \\
\hline Japan & -379 & -220 & -239 & Turkey & -151 & -108 & -146 & $\begin{array}{c}\text { Korea, } \\
\text { Rep. }\end{array}$ & -217 & -155 & -217 \\
\hline $\begin{array}{l}\text { Korea, } \\
\text { Rep. }\end{array}$ & -378 & -267 & -332 & Spain & -148 & -93 & -106 & Spain & -213 & -152 & -213 \\
\hline Russia & -345 & -248 & -317 & Vietnam & -147 & -142 & -273 & Finland & -209 & -150 & -209 \\
\hline Canada & 437 & 317 & 425 & Thailand & -92 & -94 & -120 & Canada & 365 & 261 & 365 \\
\hline
\end{tabular}

${ }^{1}$ World import differs from world export due to differences in base year statistics.

The COVID-19 recession, led to a drop in world imports of paper and paperboard of 4.8 million $\mathrm{t}(-4.1 \%)$ in 2020 . With the 2021 recovery this difference was reduced to -3.4 million $\mathrm{t}(-2.9 \%)$, but it then increased progressively to reach -4.8 million $\mathrm{t}(-3.4 \%)$ in 2030. Like production, imports decreased the most in Europe ( -2.2 million $t$, or $-4 \%$ in 2020) and in Asia ( -1.5 million $t$, or $-4.5 \%)$. India was the most affected individual country $(-465,000 t$, or $-13 \%)$ in 2020 , followed by Mexico $(-391,000 t$, or $-9.4 \%)$ and Germany $(-344,000 t$, or $-3.1 \%)$.

On the export side, the largest absolute changes were also in Asia and Europe. In Europe, exports of paper and paperboard were 3.2 million $t$ less $(-4.6 \%)$ in 2020 in the COVID-19 scenario than in the base scenario. Although the 2021 recovery reduced the difference to -2.3 million $\mathrm{t}$, it subsequently increased to reach -3.2 million $\mathrm{t}(-3.8 \%)$ in 2030. In Asia, exports were 1.3 million $t$ less (-5.5\%) in 2020, 910,000 $t$ less in 2021, and 
1.3 million $t$ less in 2030. The most affected countries were Germany-where exports of paper and paperboard were 859,000 $\mathrm{t}(-5.9 \%)$ lower in 2020 in the COVID-19 scenarioBelgium $(-370,000 \mathrm{t}$, or $-10.3 \%)$, and China $(-358,000 \mathrm{t}$, or $-5.3 \%)$.

\subsection{Effects on Price and Value Added}

Figure 1 shows the effects of the recession induced by the COVID-19 pandemic on the world prices of forest products. In accordance with the cobweb theorem, the projected prices adjusted to the 2020 and 2021 disturbances according to an oscillating pattern, converging to a long-term equilibrium. The largest relative impact was on the price of roundwood, which was 2.3 percent lower in 2020 with the COVID-19 scenario than with the base scenario. Due to the partial economic recovery, the difference reduced to $-1 \%$ in 2021 , and then stabilized at $-1.4 \%$ by 2025 . The least affected commodity was paper and paperboard, for which the price was only $0.7 \%$ lower in 2020 with the COVID-19 scenario-a difference that converged towards $-0.4 \%$ by $2022-2023$.

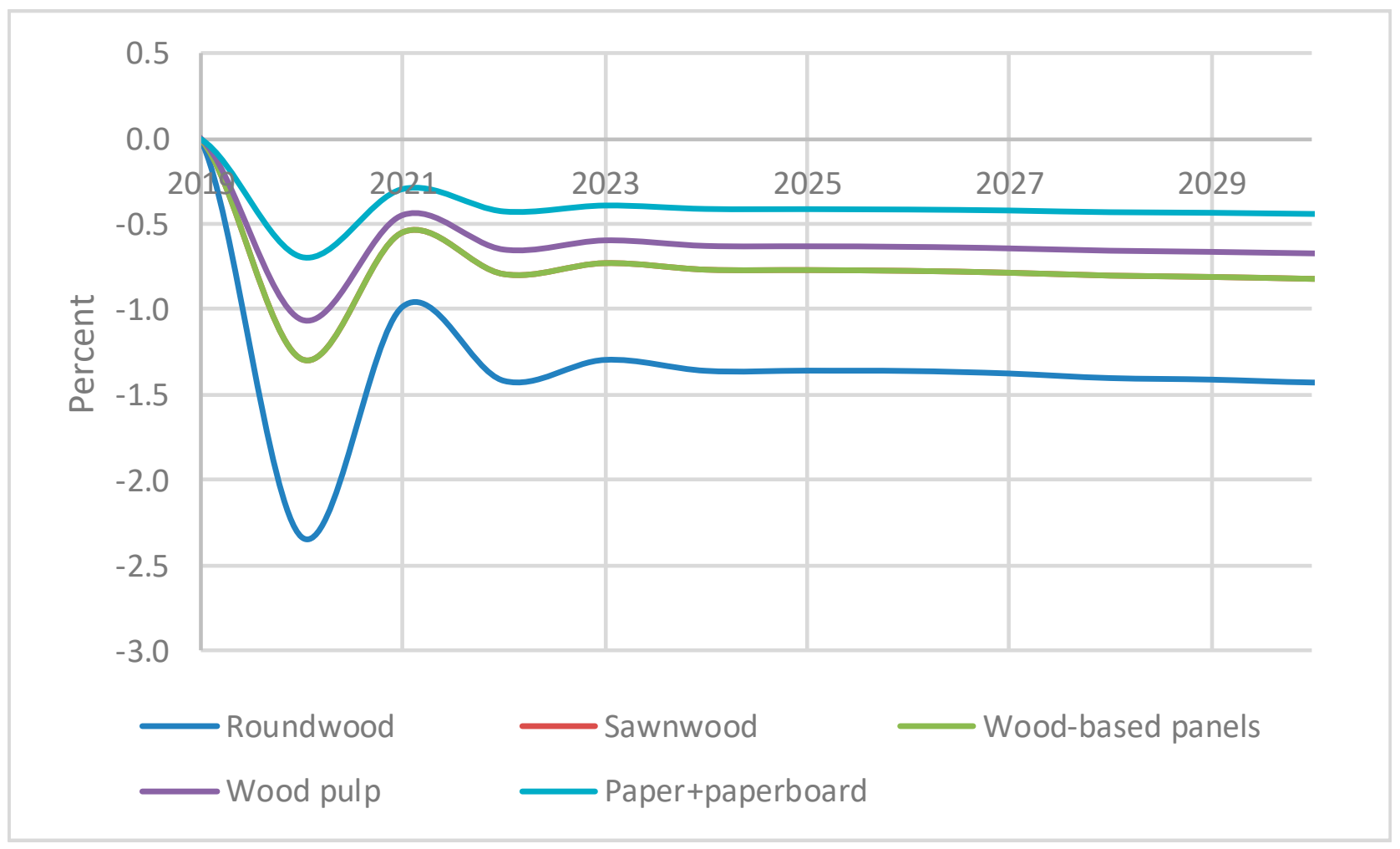

Figure 1. Dynamic adjustment of the world price of forest products to the COVID-19 economic recession, from 2019 to 2030.

Table 13 shows the combined effects of the price changes and the changes in production and consumption of the various products on the value added generated in industries, by region, and in the countries most affected by the COVID-19 recession. Here, value added was defined as the value of sawnwood, wood-based panels, wood pulp, and paper and paperboard, minus the cost of the wood products used in making them: industrial roundwood and wood pulp. The results in Table 13 show that, at the global level, the value added was USD 18.5 billion (3.8\%) lower in 2020 due to the recession induced by the COVID-19 pandemic. After the 2021 recovery the difference was reduced to USD -10.7 billion $(-2.2 \%)$, but it then increased again to reach USD -17.4 billion $(-2.6 \%)$ in 2030. Regionally, value added was most affected in Asia (USD -12.4 billion, or $-4.9 \%$ in 2020), and principally in China (USD -7.2 billion, or $-4 \%$ in 2020) and India (USD -1.9 billion, or $-32 \%$ in 2020). In contrast, the impact was negligible in North America. 
Table 13. Effect of the COVID-19 economic recession on the value added in forest industries in 2020 and 2021, by region, and in the ten most affected countries in 2020.

\begin{tabular}{ccccccc}
\hline & \multicolumn{2}{c}{2020} & \multicolumn{2}{c}{ 2021 } & \multicolumn{2}{c}{$\mathbf{2 0 3 0}$} \\
\cline { 2 - 6 } Region/Country & $\begin{array}{c}\text { Million } \\
\text { USD }\end{array}$ & \% & $\begin{array}{c}\text { Million } \\
\text { USD }\end{array}$ & \% & $\begin{array}{c}\text { Million } \\
\text { USD }\end{array}$ & $\%$ \\
& $-18,510$ & -3.8 & $-10,681$ & -2.2 & $-17,443$ & -2.6 \\
WORLD & -70 & -2.6 & -80 & -3.0 & -125 & -3.5 \\
AFRICA & -318 & -0.4 & -285 & -0.4 & -413 & -0.5 \\
N. AMERICA & -1044 & -4.4 & -665 & -2.7 & -941 & -3.2 \\
S. AMERICA & $-12,402$ & -4.9 & -6521 & -2.4 & $-11,444$ & -2.8 \\
ASIA & -171 & -2.7 & -104 & -1.6 & -155 & -2.1 \\
OCEANIA & -4505 & -3.7 & -3026 & -2.5 & -4364 & -3.0 \\
EUROPE & -7230 & -4.0 & -2802 & -1.5 & -5148 & -1.7 \\
China & -1895 & -32.2 & -1358 & -20.1 & -2747 & -13.1 \\
India & -1234 & -4.3 & -767 & -2.6 & -1173 & -3.3 \\
Germany & -698 & -2.8 & -380 & -1.5 & -455 & -1.7 \\
Japan & -695 & -4.3 & -409 & -2.5 & -598 & -3.0 \\
Brazil & -652 & -5.3 & -454 & -3.6 & -667 & -4.0 \\
Indonesia & -586 & -9.1 & -436 & -6.5 & -638 & -6.8 \\
Thailand & -430 & -9.5 & -389 & -8.2 & -778 & -8.4 \\
Vietnam & -406 & -11.5 & -304 & -8.4 & -419 & -8.2 \\
Mexico & -338 & -4.2 & -208 & -2.5 & -285 & -3.1 \\
Korea, Rep. & & & & & &
\end{tabular}

\section{Summary and Conclusions}

The first part of this paper presented the GFPMX - a model of the global forest sector anchored on the cobweb theorem. In this view, instead of consisting of a succession of perfect equilibria, a dynamic economy constantly seeks an equilibrium, typically in oscillating patterns, without necessarily reaching it. The model assumes that demand creates its own supply. Consequently, domestic and import demand are the drivers in the evolution of the global forest sector, and global import demand induces export supply. Domestic production then fills the net demand: consumption minus imports plus exports. Local prices depend on the world price. The world price is a function of production, the price of inputs, and the level of forest growing stock. Forest area changes according to a Kuznets environmental curve, while forest stock is projected via a growth-drain process.

The parameters of the GFPMX were estimated with data from the FAO production and trade statistics, the World Bank indicators, and the FAO Forest Resources Assessment. The domestic and import demand elasticities, as well as the export supply parameters, the local price parameters, and the forest stock parameters, were country-specific, estimated by quadratic programming with time-series data from 1992 to 2018.

The GFPMX was implemented as a workbook of Excel@ spreadsheets. The spreadsheet formulae automatically calibrate the GFPMX to replicate the base year data of 2018, and then project the consumption, imports, exports, production, and prices of six commodity groups, as well as forest area and forest stock, conditional on projections of GNP, population, and tariffs.

The model was applied to project the consequences of the COVID-19 recession on the global forest sector. The base scenario, without COVID-19, and the alternative scenario, with COVID-19, differed according to the Internal Monetary Fund's projections of GDP for 2020 and 2021 before the COVID-19 pandemic, and the revised projections published in January 2021, after the pandemic. The difference between the two scenarios showed the short-term impact of the COVID-19 recession on the forest sector in 2020 and 2021, and its long-term consequences up to 2030. The variables considered were production, imports, exports, and the world prices of roundwood, sawnwood, wood-based panels, wood pulp, and paper and paperboard. The results exhibited dampened oscillation patterns converging towards an equilibrium, consistent with the cobweb theorem. 
Globally, the GFPMX projected that the world production of the combined forest industries was USD 34.6 billion (2.7\%) lower in 2020 than it would have been without the COVID-19 recession. Despite a projected partial recovery in 2021, the difference was still USD -31.8 billion in 2030. The world trade of forest products in 2020 was USD 11.1 billion lower $(-4.5 \%)$ with the COVID-19 scenario than without it. Although the difference reduced to USD -6.1 billion $(-2.4 \%)$ in 2021 , it still reached USD -9.6 billion $(-3.1 \%)$ by 2030.

Since there appear to be few applications of the cobweb theorem to forest sector models-or to other economic sector models for that matter-a useful future area of inquiry could be a comparison of this type of model with, for example, partial equilibrium models [24], in terms of their forecasting accuracy, difficulty of implementation, and cost of application. Meanwhile, as a readily available open source software, with transparent data and formulae depending only on the Excel@ program, and nearly instantaneous calculations once the software has been uploaded, the GFPMX should be a useful tool for the investigation of other forest sector economic and policy issues of national, regional, and international scope, such as lumber dispute issues and other trade matters [25].

Supplementary Materials: The following are available online at https:/ / www.mdpi.com/article/1 0.3390/su13105507/s1, GFPMX software, data, and formulation.

Funding: This research received no external funding.

Institutional Review Board Statement: Not applicable.

Informed Consent Statement: Not applicable.

Data Availability Statement: The current version of the GFPMX with the data and parameters used in the application to the impact of the COVID-19 pandemic, is available at: https:/ / buongiorno.russe 11.wisc.edu/gfpm/ (accessed on 5 May 2021).

Acknowledgments: The author is grateful to Craig Johnston and Prakash Nepal for providing the long-term projections for GDP and population corresponding to the SSP2 scenario from 1999 to 2030.

Conflicts of Interest: The author declares no conflict of interest.

\section{References}

1. Adams, D.M.; Alig, R.J.; McCarl, B.A.; Callaway, J.M.; Winnett, S.M. The Forest Agricultural Sector Optimization Model: Model structure and applications; Research Paper PNW-495; U.S. Department of Agriculture, Forest Service, Pacific Northwest, Research Station: Portland, OR, USA, 1996; p. 44.

2. Buongiorno, J.; Zhu, S.; Zhang, D.; Turner, J.; Tomberlin, D. The Global Forest Products Model. (GFPM): Structure, Estimation, and Applications; Academic Press: San Diego, CA, USA, 2003; p. 301.

3. Kallio, A.M.I.; Moiseyev, A.; Solberg, B. The Global Forest Sector Model EFI-GTM-The Model Structure; European Forest Institute: Joensuu, Finland, 2004; p. 24.

4. Lauri, P.; Havlik, P.; Kindermann, G.; Forsell, N.; Bottcher, H.; Obersteiner, M. Woody biomass energy potential in 2050. Energy Policy 2013, 66, 19-31. [CrossRef]

5. Samuelson, P.A. Spatial price equilibrium and linear programming. Am. Econ. Rev. 1952, 42, 283-303.

6. Takayama, T.; Judge, G. Spatial and Temporal Price and Allocation Models; North-Holland: Amsterdam, The Netherlands, 1971; p. 528.

7. Ezekiel, M. The cobweb theorem. Q. J. Econ. 1938, 52, 255-280. [CrossRef]

8. Pashigian, B.P. Cobweb Theorem. In The New Palgrave Dictionary of Economics; Palgrave, M., Ed.; Palgrave Macmillan: London, UK, 2008.

9. Waugh, F.V. Cobweb models. J. Farm. Econ. 1964, 46, 732-750. [CrossRef]

10. Krugman, P. Demand Creates Its Own Supply. Available online: https://krugman.blogs.nytimes.com/2015/11/03/demand-crea tes-its-own-supply / (accessed on 13 May 2021).

11. Say, J.B. A Treatise in Political Economy; Grigg \& Elliot: Philadelphia, PA, USA, 1834.

12. Dinda, S. Environmental Kuznets Curve Hypothesis: A Survey. Ecol. Econ. 2004, 49, 431-455. [CrossRef]

13. Mills, R. TRIM Timber Projections: An Evaluation Based on Forest Inventory Measurements; USDA Forest Service Pacific Northwest Research Station: Portland, OR, USA, 1989; p. 27. 
14. Chudik, A.; Mohaddess, K.; Pesaran, M.H.; Raissi, M.; Rebucci, A. 2020 Economic Consequences of COVID-19: A Counterfactual Multi-Country Analysis. Available online: https://voxeu.org/article/economic-consequences-covid-19-multi-country-analysis (accessed on 13 May 2021).

15. FAOSTAT. Food and Agriculture Organization Data Base. Available online: http://www.fao.org/forestry/statistics/84922/en/ (accessed on 13 May 2021).

16. WBI. World Bank Development Indicators Data Base. Available online: https: / / databank.worldbank.org $/$ reports.aspx?source=w orld-development-indicators\# (accessed on 13 May 2021).

17. FAO. Global Forest Resources Assessment 2020. Available online: http://www.fao.org/documents/card/en/c/ca9825en/ (accessed on 13 May 2021).

18. Buongiorno, J. Country specific demand elasticities for forest products: Estimation method and consequences for long-term projections. For. Policy Econ. 2019, 106, 101967. [CrossRef]

19. Wooldridge, J.M. Introductory Econometrics, 3rd ed.; Thomson South-Western: Mason, OH, USA, 2006; p. 890.

20. IMF. World Economic Outlook Update, January 2020: Tentative Stabilization, Sluggish Recovery? Available online: https: / / www.imf.org/en/Publications/WEO/Issues/2020/01/20/weo-update-january2020 (accessed on 13 May 2021).

21. IMF. World Economic Outlook Update, January 2021: Policy Support and Vaccines to Lift Activity. Available online: https:/ / meetings.i mf.org/en/IMF/Home/Publications/WEO/Issues/2021/01/26/2021-world-economic-outlook-update (accessed on 13 May 2021).

22. Dellink, R.; Chateau, J.; Lanzi, E.; Magné, B. Long-term economic growth projections in the shared socioeconomic pathways Glob. Environ. Chang. 2007, 42, 200-214. [CrossRef]

23. KC, S.; Lutz, W. The human core of the shared socioeconomic pathways: Population, scenarios by age, sex and level of education for all countries to 2100. Glob. Environ. Chang. 2017, 42, 181-192. [CrossRef] [PubMed]

24. Latta, G.S.; Sjølie, H.K.; Solberg, B. A review of recent developments and applications of partial equilibrium models of the forest sector. J. For. Econ. 2013, 19, 350-360. [CrossRef]

25. Van Kooten, G.C.; Voss, L. International Trade in Forest Products, Lumber Trade Disputes, Models and Examples; CAB international: Wallingford, UK, 2021; p. 201. 